\title{
WILEY
}

SOCIAL SCIENCE QUARTERLY

\section{EXPLAINING GENDER DIFFERENCES IN TURNOUT USING PANEL DATA ACROSS ELECTIONS}

\begin{tabular}{|c|c|}
\hline Journal: & Social Science Quarterly \\
\hline Manuscript ID & SSQ-2019-0211.R1 \\
\hline Wiley - Manuscript type: & Original Article \\
\hline Keywords: & Gender, Elections, Turnout \\
\hline Abstract: & $\begin{array}{l}\text { The current study offers the first systematic analysis of the impact of } \\
\text { citizens' interest in and perceptions of specific elections on gender } \\
\text { differences in turnout. Using an internet panel survey conducted by the } \\
\text { Making Electoral Democracy Work (MEDW) project covering the } 2013 \\
\text { state, } 2013 \text { federal and } 2014 \text { European elections in Bavaria (Germany), } \\
\text { our probit models examine mediation and moderation effects of three } \\
\text { election-related characteristics: the issues that the citizens consider } \\
\text { most central in the elections, citizens' interest in the elections, and the } \\
\text { perceived influence among citizens of the policies of the different levels } \\
\text { of policy making on their well-being. The results indicate an overall } \\
\text { gender difference in turnout in Bavaria with women being less likely to } \\
\text { vote compared with men. Yet, this gender effect ceases to be significant } \\
\text { once citizens' attitudes towards and perceptions of specific elections are } \\
\text { controlled for. Interest in the election at hand has a particularly strong } \\
\text { and positive effect on the likelihood of voting. We find no significant } \\
\text { gender interactions, suggesting that citizens' interest in and perceptions } \\
\text { of elections have the same effect on turnout for women and men. }\end{array}$ \\
\hline
\end{tabular}




\title{
EXPLAINING GENDER DIFFERENCES IN TURNOUT
}

\author{
USING PANEL DATA ACROSS ELECTIONS
}

\begin{abstract}
The current study offers the first systematic analysis of the impact of citizens' interest in and perceptions of specific elections on gender differences in turnout. Using an internet panel survey conducted by the Making Electoral Democracy Work (MEDW) project covering the 2013 state, 2013 federal and 2014 European elections in Bavaria (Germany), our probit models examine mediation and moderation effects of three election-related characteristics: the issues that the citizens consider most central in the elections, citizens' interest in the elections, and the perceived influence among citizens of the policies of the different levels of policy making on their well-being. The results indicate an overall gender difference in turnout in Bavaria with women being less likely to vote compared with men. Yet, this gender effect ceases to be significant once citizens' attitudes towards and perceptions of specific elections are controlled for. Interest in the election at hand has a particularly strong and positive effect on the likelihood of voting. We find no significant gender interactions, suggesting that citizens' interest in and perceptions of elections have the same effect on turnout for women and men.
\end{abstract}




\section{EXPLAINING GENDER DIFFERENCES IN TURNOUT}

\section{USING PANEL DATA ACROSS ELECTIONS}

\section{Introduction}

Research on gender differences in turnout has revealed conflicting results. For example, while Engeli et al. (2006) show that women are less likely to vote compared with men, Alexander and Coffé (2018), Harell (2009), and Verba et al. (1997) find no significant gender difference, while Burrell (2005), Carreras (2018), and Coffé and Bolzendahl (2010) find a so-called reverse gender gap with women being more likely to vote than men. The empirical evidence presented in these studies typically comes from different samples of individuals in elections across different countries or across different elections in a particular country. However, as gender differences in political behaviour in general - and in turnout in particular - are correlated with a variety of aggregated contextual variables which are difficult to control for (i.e., cultural, economic, institutional or political characteristics), individual-level cross-sectional data are not ideal to make inferences.

To address this issue and increase the leverage in the empirical analysis (i.e., the principle of explaining as much as possible with as little as possible (King et al., 1994: 29)), we rely on individual-level panel data collected within the Making Electoral Democracy Work-project (MEDW) in Bavaria (Germany) during the September 2013 state and federal elections and the May 2014 European election. As the same individuals are observed for three different elections and for three different levels of policy making in a short period of time (about eight months), we can control for aggregated contextual variables and minimize as such the impact of confounding contextual variables. At the same time, the panel data maximize variation in election-specific characteristics, allowing an in-depth investigation of the influence on citizens' interest in and perceptions of specific elections on voter turnout and gender differences therein. Additionally, the well-known problems related to the comparability of survey designs or questions when making cross-national comparisons using microdata is not an issue when using panel data from a single region. To determine whether gender differences in turnout are driven by citizens' interest in and perceptions of specific elections, comparing elections in different arenas within the same region using panel data is thus preferred over comparing turnout in the same electoral arena across countries. 
Our focus on the impact of citizens' interest in and perceptions of specific elections on gender differences in turnout also adds to the existing research on gender and turnout. The existing research has mainly focused on citizens' sociodemographic profile and their political attitudes (e.g. general political interest and knowledge), as such leaving aside the effect of interest in and perceptions of specific elections. We focus on three election-specific characteristics: the issues that the citizens consider most central in the election, citizens' interest in specific elections, and the perceived influence among citizens of the policies of the different levels of policy making on their wellbeing. In contrast to most studies on gender and voter turnout which have mainly focused on mediation effects in an attempt to explain gender gaps, we explore two mechanisms: mediation (women's interest in and perceptions of elections differ from men's in ways that explain turnout) and moderation (interest in and perceptions of elections have a different effect on turnout for women and men). For example, different levels of interest in specific elections may explain why women and men are more or less likely to participate in an election, suggesting a mediation effect of interest in elections. Women and men are also known to be interested in different policy issues (as e.g. Campbell and Winters 2008; Campbell 2012; Banducci and Semetki 2002). As a consequence, if a specific election is about issues that women are particularly interested in, women's likelihood of voting may increase, whereas if issues in which men are known to be particularly interested in are central topics in the election, men's likelihood of voting may increase. The central issue of an election may thus have a different impact on the likelihood of voting for women and men, suggesting a moderation (or interaction) effect.

\section{Theory}

Various studies have investigated gender differences in voter turnout (e.g. Alexander and Coffé 2018; Burrell 2005; Carreras 2018; Coffé and Bolzendahl 2010; Engeli et al. 2006; Harell 2009; Kostelka et al. 2019; Parry et al. 1992; Verba et al. 1997). The existing research has, however, paid little attention to the effect of citizens' attitudes related to specific elections but rather looked at general political resources such as political knowledge and interest. Yet, the literature on turnout has suggested that differences in turnout depend on specific characteristics of the elections, including the closeness of a specific contest, the salience of the election, and campaign expenditures in an election (Blais 2006; Cancela and Geys 2016; Geys 2006). In addition, turnout is known to depend on which political arena and level of policy making the elections are 
held, with turnout for European elections - commonly seen as lower salience, secondorder elections - generally being significantly lower than for regional and national elections (Golder et al. 2017).

Given the relevance of election-specific characteristics, we extend the study on gender differences in turnout by focusing on the way that citizens' interest in and perceptions of specific elections may help us better understanding possible gender differences in turnout. In particular, we look at (1) citizens' perceptions of the central issue of a specific election, (2) citizens' perceptions of the extent to which the policies developed on different levels of policy making influence their life and well-being, and (3) citizens' levels of interest in a specific election. We consider both mediation and moderation effects, and argue that while the influence of policies and interest in a specific election will have a mediation effect, perceptions of the central issue of a specific elections will affect women's and men's turnout differently - suggesting a moderation effect.

\section{Mediation Effects}

Research on gender and political interest has revealed a consistent gender gap, with women being more interested in politics than men (Coffé 2013). This gender difference in levels of political interest has been presented as an important explanation for gender differences in political engagement (Coffé and Bolzendahl 2010). Given women's lower levels of interest in politics overall, it seems fair to assume that women will also be less interested in elections than men, though the size and direction of the gender difference in interest in a specific election may differ depending on the election at hand. For example, various studies (Coffé 2013; Norris et al. 2004; Sánchez-Vítores 2018) have suggested a greater interest among women in local issues compared with men, whereas men show greater levels of political interest compared with women when national and international issues are considered. Togeby (1994) and Nelsen and Guth (2000) have confirmed that women are less interested in more distant political institutions such as the EU and other international organizations. In their US studies, Verba et al. (1997) and Schlozman et al. (1994) show that that men tend to be somewhat more likely than women to be very interested in national politics. Asking explicitly about political interest in national politics in their face-to-face survey among a sample of British respondents, Pattie et al. (2004) show that men tend to be more likely to be 'very interested' than women. 
Starting from the premise that (general) political interest strongly affects turnout (e.g. Denny and Doyle 2008; Hadjar and Back 2010; Smets and Van Ham 2013; Söderlund et al. 2011), it seems fair to assume that interest in a specific election will increase the propensity to vote. Considering the expected differences in women's and men's interest in elections and in elections on different levels of policy making described above, our first hypothesis reads:

Hypothesis 1: Given that women and men have different levels of interest in specific elections, the effect of gender on turnout will disappear once interest in specific elections is controlled for.

Given women's overall lower levels of interest as well as political knowledge and political efficacy (Coffé and Bolzendahl 2010; Fraile 2014), women may also be more likely to think that elections and policies developed in different levels of policy making do not influence their lives and well-being. If women and men do indeed have different opinions about the extent to which elections and policies influence their lives and wellbeing, this may also help explaining possible gender differences in turnout. As with political interest, differences may however exist depending on the level of policy making. For example, related to men's greater interest in national politics (Coffé 2013; Sánchez-Vítores 2018), men may feel that national policies have a greater influence on their lives and consequently be more likely to vote in federal (national) elections compared with women. Based on the idea that women and men will have different levels of feelings about the extent to which specific elections will influence their lives and well-being and that such feelings affect the likelihood of voting, we can formulate the following hypothesis:

Hypothesis 2: Given that women and men feel that different levels of policy making influence their well-being to a different extent, the effect of gender on turnout will disappear once citizens' perceptions of the extent to which different levels of policy making influence their lives are controlled for.

\section{Moderation Effect}

So far, we have suggested two hypotheses about how interests in and perceptions of elections may explain gender differences in turnout. Explanations for turnout may however also differ between women and men. Coffé and Bolzendahl (2010) have indeed shown how some demographic and attitudinal characteristics influence participation differently among men and among women. In particular, we expect the central issue of a specific election to encourage women and men differently. Women 
have been found to be interested in different policy issues than men. Campbell and Winters (2008) show among their British sample that women are more interested in domestic political issues (health, education, law and order) than their male counterparts (see also Campbell 2012). Men, in their turn, are more likely to be interested in general politics, foreign policy and partisan politics. In a similar vein and using Eurobarometer data, Banducci and Semetki (2002) found that women are more likely to pay attention to "feminine" issues such as environmental news and news about social issues while men are more likely to pay attention to "masculine" issues such as political, economic and foreign policy news. Relatedly, Campbell (2012) has also shown gender differences in political priorities, with amongst others women giving greater priority to education and health than men, who prioritize relations with the European Union, taxation and the economy.

Given that women and men are interested in different issues (e.g. Banducci and Semetki 2002; Campbell and Winters 2008), we expect central topics in elections to have a different effect on the likelihood of voting among women compared with men. In particular, a "feminine" issue (e.g. education, social welfare, health, family) as central issue of a specific election is expected to increase women's likelihood of voting whereas a masculine issue (e.g. economics, defence, finance) as central issue of an election is anticipated to increase men's likelihood of voting. In sum, our hypothesis reads as follows:

Hypothesis 3: A feminine issue (compared with a masculine issue) as central issue in a specific election is expected to have a stronger positive effect on turnout among women than among men.

\section{Data and methods}

To test our hypotheses, we rely on an internet panel survey conducted by the MEDW project covering the 2013 state, 2013 federal and 2014 European elections in Bavaria (Germany) (Blais 2010). The panel was conducted in five waves. Wave 1 preceded the 2013 state election, Wave 2 was fielded between the 2013 state election and the 2013 federal election, and Wave 3 followed the 2013 federal election. Waves 4 and 5 were organized before and after the 2014 European election, respectively. ${ }^{1}$ Our analyses rely

\footnotetext{
${ }^{1}$ The state election was held on September 15, 2013; the pre-election survey (wave 1) was conducted between August 30 and September 14, 2013, and the post-election survey (wave 2) between September 16 and September 21, 2013. The representative post-election sample includes 4,780 respondents. The federal election was held on September 22, 2013; the pre-election survey was conducted at the same time
} 
on the sample of 2,584 respondents who took part in the five waves of the surveys. In each analysis, listwise deletion of observations with missing data on the independent variables was used (Allison 2002). We rely on the post-election waves to measure our dependent variable (voting) and our main explanatory variables, and on the pre-election waves to measure the control variables.

We have three methodological and substantive reasons for using the Bavaria panel to address our research question. First, as we are examining the behavior of the same individuals across elections in three different electoral arenas in the same region, variation in our main explanatory variables (election-specific characteristics) is maximized, while cultural, economic or institutional variables are constant. When observing the same individuals in different electoral arenas confounder variables (i.e. contextual aggregated variables) do not affect the results, whereas this may be an issue when observing individuals from different countries, particularly when dealing with issues affected by cultural factors.

Second, the surveys are directly comparable. Apart from having the same technical characteristics, the post-election questionnaires include the same questions. ${ }^{2}$ As the variables have been measured exactly in the same way and the methodological design of all surveys is similar, the ex-post harmonization of data is not an issue and the data are perfectly comparable (Granda et al. 2010).

Third, the three elections in Bavaria were held within a 252-day period. When elections are held so close to one another, contextual factors, and in particular the party system, are largely constant and their effect is minimized. As can be seen in Table 1, the party system in Bavaria, including the distribution of partisan support, is relatively stable over the three elections.

\section{[Table 1 about here]}

The Christian Social Union (CSU) gained the greatest support in all three elections examined in the current study - reaching almost 50 percent in the 2013 federal

\footnotetext{
as the post-election survey of the state election (between September 16 and September 21, 2013), and the post-election survey (wave 3) between September 23 and September 28, 2013. The representative postelection sample includes 4,041 respondents. The European election was held on May 25, 2014; the preelection survey (wave 4) was conducted between May 12 and May 20, 2014, and the post-election survey (wave 5) between May 26 and June 2, 2014. The representative post-election sample includes 2,584 respondents.

2 All surveys were conducted by Harris International, which contracted Infratest as sample provider. Most of the recruitment of panelists was done through aggregators to optimize the probability that the panel reflects the overall composition of the population. The sampling was based on a stratified, quota-based approach (according to age, gender, and education). For further details about the Making Electoral Democracy Work-project, see http://www.chairelectoral.com/medw.html
} 
elections, despite a political scandal that became public before the elections (Kauder and Potrafke 2015). While CSU's electoral strength has declined during in the most recent elections, the CSU has traditionally dominated the Bavarian political system (Hepburn 2008; James 2009). There has only been one election instance since 1946 (after the 1954 elections) of a Bavarian government that did not contain the CSU, and most of the time, the party governed on its own. The CSU has a close-knit local structure (Falkenhagen 2013). The party is a center-right oriented party which classifies itself as a Christian-conservative party which aims at strengthening Bavaria's position vis-à-vis the German federation (Hepburn 2008; Zolleis and Wertheimer 2013). The CSU is a clearly regionalist party that focuses strongly on the Bavarian identity and mobilizes around the concept of Heimat (Hepburn 2008). While it forms an alliance with the Christian Democratic Union (CDU), it is a fully independent party, "with separate party programmes and congresses, organizational and membership structures, and the existence of a CSU Landesgruppe in the Bundestag” (Hepburn 2010: 537).

Bavaria's political system has distinct traditions and political culture which distinguish the region from the rest of Germany (Hepburn 2010). It also has a strong territorial identity and a unique culture within Germany, including a separate dialect, cuisine, and folklore, and CSU-led Bavarian governments have promoted "a mixed economy of Laptop und Lederhose that combines market liberalism with an active policy of state economic intervention and social protection" (Hepburn 2008: 189).

Similar to the electoral system used for Germany federal elections, Bavaria uses a mixed-member proportional representational system to elect the members of its regional parliament and the percentage of women in the Bavarian parliament has been comparable to the percentage of women in the federal parliament (Arrequi Coka et al. 2017).

\section{Dependent Variable}

Our dependent variable, voting, is a dichotomous variable and takes the value 1 if the respondent voted in the corresponding election and 0 if they did not vote.

\section{Explanatory Variables}

Gender is coded dichotomously with 0 for men and 1 for women. The three electionrelated variables are: the central issue of the election, the influence of the policies developed on the corresponding level of government on the respondents' well-being, and the respondents' interest in the election. To measure the issue of the election, we 
rely on the question asking respondents what they thought was the central issue in the election. ${ }^{3}$ The variable was recoded to distinguish masculine from feminine issues. Additionally, two more categories were created: one capturing the opinion that the election was mainly about choosing the best people and a 'Don't know' category. To distinguish masculine from feminine issues, we relied on existing literature defining feminine issues as those associated with the "private" sphere, reflecting women's social construction as being more nurturing, people-oriented and familial, and masculine issues as those associated with the "public" sphere given men's traditional gender role as head of the household, financially and legally (e.g. Bolzendahl 2014; Coffé et al. 2019; Schwindt-Bayer 2010; Heath et al. 2005; Thomas 1994; Towns 2003). We coded taxes, infrastructure, crime, European Union, European crisis and immigration as masculine issues and social welfare, education, energy and environment as feminine issues. In the analyses below, the category referring to masculine issues is used as the reference category. The influence of the policies of the state, the federal government and the EU, is measured by the question asking how the policies developed on the three different levels influence respondents' and their family's well-being. The answer categories range from 0 (no impact at all) to 10 (a huge impact). Finally, to measure interest in the election, we rely on a question asking respondents how interested they were in the state, federal and European election on an 11-point scale ranging from 0 (no interest at all) to 10 (a great deal of interest).

All variables measuring respondents' interest in and perceptions of the elections have been measured for each election (state, federal and European) specifically.

\section{Control Variables}

Our models also include conventional individual-level correlates of electoral turnout (Smets and van Ham 2013). Variables taken from the resource model explaining

\footnotetext{
${ }^{3}$ The specific question, asked in the three post-election surveys, has two parts. First, respondents were asked whether they thought that the election was mostly about what should be done on the most important issues of the day or about choosing the best persons to govern in Bavaria. Answer categories were (1) Issues of the day, (2) Best people to govern, (3) Don't Know. Respondents who answered 1 (issues of the day) received a follow-up question asking which issue the election was mainly about. The provided answer were: (1) Taxes, (2) Social welfare, (3) Education, (4) Infrastructure, (5) Agriculture, (6) Crime, (7) Energy and the environment, (8) Immigration, (9) European Union, (10) European Crisis, (88) Other, (99) Don't know. Both questions were combined in the operationalization of our variable of the central issue of the election. Observations where respondents said that the specific election was about issues but who were not able to choose a specific issue in the follow-up question (90 out of 4,685 observations) were not included in the analyses.
} 
turnout, are education, age, urbanization, marital status and employment status.

Education refers to the respondent's highest level of education and is a continuous variable ranging from (1) lower secondary to (7) tertiary complete. Age is a continuous variable (in years). The variable urban living refers the size of the place where the respondent lives on a scale ranging from (1) less than 2,000 inhabitants to (7) more than 500,000 inhabitants. Marital status is coded 0 if the respondent is single or living alone, divorced or widowed and 1 if the respondent is married or in a relationship.

Employment status is a categorical variable coded 0 if the respondent is unemployed, 1 for a full-time job, 2 for a part-time job and 3 for other situations.

Our models also include two control variables of the mobilization model of turnout: religiosity and union membership. Religiosity captures how important religion is for the respondent, ranging from (1) not very important to (4) very important. Union membership is a dichotomous variable taking the value of 1 if anyone in the household belongs to a union and 0 otherwise.

A next set of control variables included in our analyses take explanations which are central in the psychological model of electoral turnout into account, namely political knowledge, closeness to a party, and regional attachment. ${ }^{4}$ Political knowledge is a 4point variable capturing whether the respondent knows the name of the German Finance minister (Wolfgang Schäuble), the name of the American president between 2008 and 2012 (Barack Obama), and that "In Bavaria, a party that gets 20 percent of the list votes get about 20 percent of the seats". ${ }^{5}$ Correct answers have been summed up, meaning that the variable indicates the number of correct answers given. ${ }^{6}$ Feeling close to $a$ political party is a dichotomous variable taking the value of 0 if the respondent does not

\footnotetext{
${ }^{4}$ Another political attitudinal characteristic known to relate to turnout and to gender differences in political participation is political interest (e.g. Coffé and Bolzendahl 2010; Verba et al. 1997). General political interest and interest in specific elections - one of our key variables - are however strongly correlated, with a correlation of .76 between general political interest and interest in the state election. In addition, political interest is a very general measure which may be interpreted in different ways. Our main explanatory variable, measuring respondents' interest in a specific election, has the advantage of being more specific about a particular election. Finally, general political interest and political knowledge also strongly correlate (.34) and the latter has been found to have stronger effect on electoral turnout than the first (Smets and van Ham 2013). Therefore, general political interest is not included in the analyses.

5 The specific questions, which were included the first of the five waves of the panel (which is the state pre-election survey), are the following:

(1) "Many people do not remember the names and statements of politicians. Do you recall...

(a) The name of the German Finance minister: (1) Peer Steinbrück, (2) Helmut Linssen, (3) Wolfgang

Schfgang, (4) Rainer Brüderle, (5) Guido Westerwelle, (9) Don't know.

(b) The name of the American president between 2008 and 2012?; (1) Donald Trump, (2) George W. Bush, (3) Barack Obama, (4) Joe Biden, (5) Colin Powell, (9) Don’t know.

(2) Please indicate whether the following statement is true or false: In Bavaria, a party that gets 20 percent of the list votes get about 20 percent of the seats. True (1), False (2), Don't know (9)."

6 The "Don't Know/Not Applicable" response has been considered as an incorrect answer.
} 
feel close to any particular political party, and 1 if they feel close to any particular party. Regional attachment measures how close respondents feel to Bavaria, Germany and Europe on a scale from (0) not attached at all to (10) very strongly attached. Finally, we control for whether the Election is State, federal or European.

The variables measuring the closeness to a political party, election arena and regional attachment are measured specifically for each election (state, federal and European).

The descriptive statistics for all control variables are displayed in Table A1 in the Appendix.

\section{Analytical Strategy}

The empirical explanatory analysis proceeds in three steps. The first step examines the gender difference in the propensity to vote including the level of policy making and controlling for the resource, mobilization and psychological models of individual level voter turnout. The model is the following:

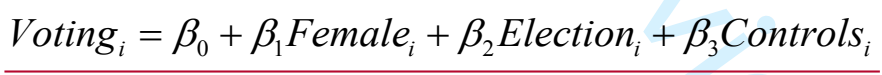

The second step tests the mechanisms behind the gender difference in turnout, namely the election-related variables introduced in the theoretical section: the issues that the citizens considered most central in the election, citizens' interest in the elections, and the perceived influence of the policies of the different levels of policy making on citizens' well-being. If the gender gap in turnout is a function of citizens' interest in the elections (Hypothesis 1) and the perceived influence of the policies of the different levels of policy making (Hypothesis 2), gender should not significantly affect turnout when adding the three election-related variables to the previous model. The model is the following:

Voting $_{i}=\beta_{0}+\beta_{1}$ Female $_{i}+\beta_{2}$ Election $_{i}+\beta_{3}$ Controls $_{i}+\beta_{4}$ Issue $_{i}+\beta_{5}$ Influence $_{i}$

$+\beta_{6}$ Interest $_{i}$

The final and third step investigates the interaction between gender and the central issue of the elections. This model allows us to test Hypothesis 3 which suggests that a feminine issue as the central issue of a specific election will have a stronger positive 
effect on women's likelihood of voting than on men's compared with a masculine issue. The model is the following:

Voting $_{i}=\beta_{0}+\beta_{1}$ Female $_{i}+\beta_{2}$ Election $_{i}+\beta_{3}$ Controls $_{i}+\beta_{4}$ Issue $_{i}+\beta_{5}$ Influence $_{i}$

$+\beta_{6}$ Interest $_{i}+\beta_{7}$ Female Issue $_{i}$

Given that the dependent variable is dichotomous, Probit regressions were run. Since each individual is asked three times about whether they voted or not, all standard errors are clustered by respondent to account for non-independence in the data structure. When running the regression models, the data from the three elections have been pooled to increase the sample size and obtain more robust estimates. Finally, the data have been weighted by age, gender, education and likelihood of voting (as provided in the dataset) to reflect the actual composition of the Bavarian population. ${ }^{7}$

\section{Results}

\section{Descriptive Analyses}

The first piece of evidence about possible gender differences in turnout is shown in Tables 2 and 3. Roughly speaking, the data show that men are more likely to vote than women. As seen in Table 2, 65 percent of men did vote versus 59 percent of women when the observations for the three postelection surveys are pooled. This difference is statistically significant at the .001 percent level. In state and federal elections, the gender gaps are respectively 11 and 8 percent points, both in favor of men and both statistically significant. While these results go against the observations of small to no and even reversed gender gaps made in various countries, they do confirm the finding of Kittilson's (2016) for Germany. Using data from the 2011-2013 Comparative Study of Election Systems (CSES), Kittilson (2016) revealed a gender gap of almost eight percentage points in favour of men's turnout in Germany. We find no significant gender difference in the likelihood of participating in the European elections; elections in which turnout for both women and men is very low. ${ }^{8}$

\footnotetext{
${ }^{7}$ The main findings of our analyses are very similar when estimating the models without this weight. ${ }^{8}$ Using MEDW data, we compared attachments to different levels of policy making in Bavaria with attachments to different levels of policy making in Lower Saxony (Germany), île de France and Provence in France, and Catalonia and Madrid in Spain. The Bavarian sample had an average score of 4.9 on an 11point scale measuring how strong respondents felt attached to Europe, which was not particularly low compared with other regions (lowest score: 4.3 in Provence; highest score: 5.3 in Lower Saxony). The scores in Bavaria for attachment to one's region and country were also comparable to those of the other regions.
} 
[Table 2 about here]

Table 3 illustrates the gender difference in turnout in a different way and presents the number of elections (out of the three elections) women and men voted in. Respondents are thus divided in four different groups: those who voted in the three elections, those who voted in two of them, those who voted only in one of them and, finally, those who did not vote in any of the elections. As can be seen, there are more male than female core voters: 59 percent of men voted in all three elections, compared with only 48 percent of women. Conversely, there are significantly more female than male peripheral voters (who voted in only one election) and substantially more female than male abstainers: respectively 15 percent compared with 10 percent. $^{9}$

[Table 3 about here]

Table 4 further explores gender differences in the key variables (for the three electoral arenas separately): the central issue of the election, the influence of the policies of the different levels of policy making on the respondent's and their family's well-being, and interest in the election.

\section{[Table 4 about here]}

Not surprisingly, both men and women are less interested in the European elections compared with the state and federal elections, and perceive the policies of the EU less influential on their well-being than the policies of state and federal governments. Gender differences in interest in the elections and in perceptions of the influence of the different levels of policy making however occur. In particular, and reflecting the gender differences in turnout displayed in Table 2, the descriptive data show that men and women are statistically different in their interest in the state and federal elections with men having greater levels of interest in both elections compared with women. There is no significant gender difference in interest in European elections. Women also attribute lower scores to the influence of the policies of the federal government on their wellbeing compared with men. Women generally have the same perceptions as men about the central issue of elections. Yet, women are significantly more likely to say that they do not know the central issue of the federal election compared with men, confirming women's lower levels of political knowledge and greater likelihood of answering 'don't know' (e.g. Dow 2009; Fraile 2014; Lizotte and Sidman 2009). Men - in their turn - are

\footnotetext{
${ }^{9}$ The majority (61.5 percent; 59.3 percent among men, 62.5 percent among women) of those who only voted in one election voted only at the federal election.
} 
significantly more likely to argue that the federal election were about choosing the best people compared with women.

It is also worth noting that, as suggested in the theoretical section, respondents who believe that policies developed on a specific level of policy making influence their and their family's well being are significantly more interested in the election taking place on that level of policy making. The two variables correlate significantly (Corr.=.39); a correlation which is slightly higher among men (Corr.=.42) compared with women $($ Corr. $=.36)$

\section{Explanatory Analyses}

Turning to our explanatory analyses, Table 5 shows the results of the probit regression analyses.

\section{[Table 5 about here]}

The first model shows that there is a statistically significant (at the .05 percent level) gender difference in turnout even when controlling for the resource, mobilization and psychological model variables and the election dummies: women are less likely to vote than men. However, when including the variables capturing citizens' interest in and perceptions of specific elections, the gender effect ceases to be statistically significant. The interest individuals have in the election has a particularly strong and positive effect: the greater the interest, the greater the probability of voting. The perceived influence of the different levels of policy making on the respondent's and their family's well-being does not affect the probability of voting. The central issue of the specific election campaign as perceived by the respondents has also no direct effect on turnout, though those who are not able to say what the most important issue in the election campaign was are less likely to vote compared with those arguing that the central issue of the election was a masculine issue. This is in line with previous research (Ragsdale and Rusk 1995) which showed that issue awareness significantly increased the likelihood of having voted in the 1990 US midterm senate races.

Overall, the analysis supports Hypothesis 1 referring to the effect of interest in specific elections. An analysis only including interest in the specific elections of our main explanatory variables (see Model 2 in Table A2 in the Appendix) does indeed reveal that gender does no longer have a significant effect once interest in the specific elections is included. The effect of gender also ceases to be significant at the conventional .05 percent level when only the influence of policies on well-being is included of our main explanatory variables (see Model 1 in Table A2 in the Appendix). 
While this offers some support for Hypothesis 2, it should be noted that the decrease in the effect of gender (as indicated by the coefficient) when the influence of policies is included separately is minor.

Based on the results of model 2 in Table 5, the significant effect of interest in the election is shown in Figure 1, for women and men separately.

[Figure 1 about here]

For those respondents who are not interested at all in the election (i.e., value 0), the probability of voting is .30 if they are male and .25 if they are female. For those respondents who are very interested in the election (i.e., value 10), the probability of voting is .89 if they are male and .86 if they are female. Both among women and men, interest in the specific election thus has a strong effect on the likelihood of voting, and the effect is largely the same for women and men. A model including an interaction between gender and interest in the election (not shown but available upon request) indeed confirms that the interaction term is not significant, suggesting that the effect is similar for women and men.

Turning to our third and final model, which includes an interaction between gender and the central issue of a specific election, we find no significant interaction. Contrary to our expectation specified in Hypothesis 3, the effect of the central issue of an election being feminine (rather than a masculine issue) on the likelihood of voting is similar for women and men.

We also empirically explored gender interactions with the other two central variables of our study: influence of policies on well-being and interest in the election (see Models 1 and 2 in Table A3 in the Appendix). None of the interactions were significant, indicating that the effects of interest in the election and perceived influence of policies are similar for women and men. Finally, given the variation in turnout and the gender gap in different elections, we also empirically explored gender interactions with the levels of policy making. The analysis (see Model 3 in Table A3 in the Appendix) shows a significant $(\mathrm{p}<.05)$ and positive interaction between being female and European elections, suggesting that the difference in voting for the European elections compared with the state elections is larger for men compared with women. Predicted probabilities show that - once election-specific characteristics and individual sociodemographic characteristics have been taken into - men's probability to vote in the state elections is .72 compared with .64 for women. A significant gender difference in the likelihood of voting in the 2013 state elections thus remained once election-specific and individual characteristics were controlled for. By contrast, women's and men's 
probability to vote in European elections was exactly the same: .57. The probability of men and women to vote in the federal elections was also virtually the same, respectively .74 and .72. Thus, while Table 2 presenting bivariate relationships between gender and turnout revealed a significant gender difference in turnout in federal elections, with men being more likely to vote compared with women, such gender difference is no longer apparent once individual sociodemographic variables and election-specific characteristics are taken into account.

\section{Conclusion}

Given the major implications of turnout on the representativeness of politics, turnout deserves our continuing scholarly attention. Using individual-level panel data collecting during the 2013-2014 federal, state and European elections in Bavaria, and thus observing electoral behavior of the same individuals in three different arenas in a very short period of time, offered an exceptional opportunity to focus on the effect of election-specific characteristics. It allowed us to perfectly control contextual and sociodemographic and general political attitudinal individual level determinants of electoral turnout while providing substantial variation in election-specific characteristics, in particular: the central issue of an election, the influence of policies developed on the different levels of government on the respondent's and their family's well-being, and the interest in an election.

In sum, the study revealed an overall gender difference in turnout in Bavaria, with women being less likely to vote compared with men, even when including the conventional individual-level correlates of turnout suggested in the resource, mobilization and psychological models of voter turnout. Yet, this gender difference ceases to be significant once interest in and perceptions of specific elections are controlled for. Interest in the election at hand has a particularly strong and positive effect: the greater the interest in an election, the greater the probability of voting. Contrary to our expectations, the extent to which citizens perceive policies to have an influence on their and their family's well-being does not affect turnout. Also contrary to our hypotheses, the central issues of an election do not impact the likelihood of voting differently for women than for men.

Having taken advantage of panel data on turnout in various elections held in short period of time, the current study presented - to the best of our knowledge - a first, detailed and systematic test of the extent to which and how interest in and perceptions of specific elections help explain and moderate possible gender differences in turnout. 
As always, however, various questions remain, with the main question being the generalisability of our findings. Indeed, our evidence comes from a single German region, Bavaria. While the revealed gender difference in turnout in federal elections confirms previous findings for Germany overall (Kittilson 2016), Bavaria is one of Germany's conservative heartlands in which the conservative party CSU has dominated politics for decades (Kauder and Potrafke 2015). The political culture in Bavaria is also more homogenous than that of Germany (Zolleis and Wertheimer 2013). A crucial question thus is whether our findings on the relevance of election-specific characteristics when explaining gender differences in turnout can be extrapolated to other countries or regions. Clearly, more panel data covering different electoral arenas in other contexts are important before drawing far-reaching and general conclusions. For now, we can conclude that explanations for gender differences in turnout seem to be incomplete without also taking election-specific characteristics into account. When people have an interest in a specific election and know the central issue of an election, they are more likely to go to the polls, which helps explain why men and women turn out to different degrees.

\section{References}

Alexander, Amy C. and Hilde Coffé. 2018. Women's Political Empowerment Through

Public Opinion Research: The Citizen perspective. In: Amy C. Alexander, Catherine Bolzendahl and Farida Jalalzai (Eds.) Measuring Women's Political Empowerment across the Globe: Strategies, Challenges and Future Research. New York: Palgrave Macmillan. Pp. 27-53.

Allison, Paul D. 2002. Missing Data. Thousand Oaks: Sage Publications.

Arregui Coka, Daniela, Ronny Freier and Johanna Mollerstrom. 2017. DIW Economic

Bulletin: Women in Politics, 37: Gender Parity in German Politics: Further Effort Required. Berlin: Deutsches Institut für Wirtschafsforschung.

Banducci, Susan and Holli A. Semetko, 2002. Gender and Context: Influences on Political Interest in Europe. Paper Presented at the Annual MPSA Conference. Blais, André. 2006. What Affects Turnout? Annual Review of Political Science 9: 111125.

Blais, André. 2010. Making Electoral Democracy Work. Electoral Studies 29: 169-70. Bolzendahl, Catherine. 2014. Opportunities and Expectations. The Gendered Organization of Legislative Committees in Germany, Sweden, and the United States. Gender \& Society 28(6): 847-876. 
Burrell, Barbara C. 2005. Gender, Presidential Elections and Public Policy: Making Women's Votes Matter. Journal of Women, Politics and Policy 27(1): 31-50.

Campbell, Rosie. 2012. What Do We Really Know about Women Voters? Gender, Elections and Public Opinion. The Political Quarterly 83(4): 703-710.

Campbell, Rosie and Kristi Winters. 2008. Understanding Men's and Women's Political Interests: Evidence from a Study of Gendered Political Attitudes. Journal of Elections, Public Opinion and Parties 18: 53-74.

Cancela, João and Benny Geys. 2016. Explaining Voter Turnout: A Meta-Analysis of National and Subnational Elections. Electoral Studies 42: 264-275.

Carreras, Miguel. 2018. Why No Gender Gap in Electoral Participation? A Civic Duty Explanation. Electoral Studies 52: 36-45.

Coffé, Hilde. 2013. Women Stay Local, Men Go National and Global? Gender Differences in Political Interest. Sex Roles 69(5): 323-338.

Coffé, Hilde and Catherine Bolzendahl. 2010. Same Game, Different Rules? Gender Differences in Political Participation. Sex Roles 62: 318-333.

Coffé, Hilde, Catherine Bolzendahl and Katia Schnellecke. 2019. Parties, Issues and

Power: Women's Partisan Representation on German Parliamentary Committees. European Journal of Politics and Gender 2(2): 257-281.

Denny, Kevin and Orla Doyle. 2008. Political Interest, Cognitive Ability and Personality: Determinants of Voter Turnout in Britain. British Journal of Political Science 38(2): 291-310.

Dow, Jay K. 2009. Gender Differences in Political Knowledge: Distinguishing Characteristics-Based and Returns-Based Differences. Political Behavior 31(1): 117-136.

Engeli, Isabelle, Thanh-Huyen Ballmer-Cao and Marco Giugni. 2006. Gender Gap and Turnout in the 2003 Federal Elections. Swiss Political Science Review 12(4): $217-$ 242.

Falkenhagen, Frédéric. 2013. The CSU as an Ethno-Regional Party. German Politics 22(4): 396-420.

Fraile, Marta. 2014. Do Women Know Less About Politics Than Men? The Gender Gap in Political Knowledge in Europe. Social Politics 21(2): 261-289.

Geys, Benny. 2006. Explaining Voter Turnout: A Review of Aggregate-Level Research. Electoral Studies 25(4): 637-663. 
Golder, Sona N., Ignacio Lago, André Blais, Elisabeth Gidengil and Thomas Gschwend. 2017. Multi-Level Electoral Politics: Beyond the Second-Order Election Model. Oxford: Oxford University Press.

Granda, Peter, Christof Wolf and Reto Hadordn. 2010. Harmonizing Survey Data. In Janet A. Harkness, Michael Braun, Brad Edwards, Timothy P. Johnson, Lars Lyberg, Peter Ph. Mohler, Beth-Ellen Pennell and Tom W. Smith (Eds.). Survey Methods in Multinational, Multiregional, and Multicultural Contexts. New Jersey: Wiley, pp. 315-334.

Hadjar, Andreas and Michael Beck. 2010. Who Does Not Participate in Elections in Europe and Why is This? European Societies 12(4): 521-542.

Harell, Allison. 2009. Equal Participation but Separate Paths?: Women's Social Capital and Turnout. Journal of Women, Politics and Policy 30(1): 1-22.

Heath, Roseanna Michelle, Leslie A. Schwindt-Bayer and Michelle M. TaylorRobinson. 2005. Women on the Sidelines: Women's Representation on Committees in Latin American Legislature. American Journal of Political Science 49(2): 420436.

Hepburn, Eve. 2008. The Neglected Nation: The CSU and the Territorial Cleavage in Bavarian Politics. German Politics 17(2): 184-202.

Hepburn, Eve. 2010. Small Worlds in Canada and Europe: A Comparison of Regional Party Systems in Quebec, Bavaria and Scotland. Regional and Federal Studies 20(4-5): 527-544.

James, Peter. 2009. End of an Era? The Landtagswahl in Bavaria, September 2008. German Politics 18(1): 103-109.

Kauder, Björn and Niklas Potrafke. 2015. Just Hire your Spouse! Evidence from a Political Scandal in Bavaria. European Journal of Political Economy 38: 42-54. King, Gary, Robert O. Keohane and Sidney Verba. 1994. Designing Social Inquiry Scientific Inference in Qualitative Research. Princeton, New Jersey: Princeton University Press.

Kittilson, Miki Caul. 2016. Gender and Political Behavior. Oxford Research Encyclopedia of Politics. Online Publication. Doi:

10.1096/acrefore/9780190228637.013.71

Kostelka, Filip, André Blais and Elisabeth Gidengil. 2019. Has the Gender Gap in Turnout Really Disappeared? West European Politics 42(3): 437-463.

Lizotte, Mary-Kate and Andrew H. Sidman. 2009. Explaining the Gender Gap in Political Knowledge. Politics and Gender 5(2): 127-151. 
Nelsen, Brent F. and James L. Guth. 2000. Exploring the Gender Gap: Women, Men and Political Attitudes toward European Integration. European Union Politics 1(3): 267-291.

Norris, Pippa, Joni Lovenduski and Rosie Campbell. 2004. Gender and Political Participation. London: The Electoral Commission.

Parry, Geraint, George Moyser and Neil Day. 1992. Political Participation and Democracy in Britain. Cambridge, UK: Cambridge University Press.

Pattie, Charles, Patrick Seyd and Paul Whiteley. 2004. Citizenship in Britain: Values, Participation and Democracy. Cambridge: Cambridge University Press.

Ragsdale, Lyn and Jerrold G. Rusk. 1995. Candidates, Issues, and Participation in Senate Elections. Legislative Studies Quarterly 20(3): 305-327.

Sánchez-Vítores, Irene. 2018. Different Governments, Different Interests: The Gender Gap in Political Interest. Social Politics: International Studies in Gender, State \& Society. Advance Online Publication. Doi: 10.1093/sp/jxy038

Schlozman, Kay Lehman, Nancy Burns and Sidney Verba. 1994. Gender and the Pathways to Participation: The Role of Resources. Journal of Politics 56: 963-990. Schwindt-Bayer, Leslie A. 2010. Political Power and Women's Representation in Latin America. Oxford, New York: Oxford University Press.

Smets, Kaat and Caroline van Ham. 2013. The embarrassment of riches? A metaanalysis of individual-level research on voter turnout. Electoral Studies 32: 344359.

Söderlund, Peter, Hanna Wass and André Blais. 2011. The Impact of Motivational and Contextual Factors on Turnout in First- and Second-Order Elections. Electoral Studies 30: 689-699.

Thomas, Sue. 1994. How Women Legislate. Oxford: Oxford University Press.

Togeby, Lisa. 1994. The Gender Gap in Foreign Policy Attitudes. Journal of Peace Research 31(4): 375-392.

Towns, Ann. 2003. Understanding the Effects of Larger Ratios of Women in National Legislatures: Proportions and Gender Differentiation in Sweden and Norway. Women \& Politics 25(1): 1-29.

Verba, Sidney, Nany Burns and Kay Lehman Schlozman. 1997. Knowing and Caring About Politics: Gender and Political Engagement. The Journal of Politics 59(4): 1051-1072.

Zolleis, Udo and Carina Wertheimer. 2013. Is the CSU Still a Volkspartei? German Politics 22(1-2): 97-113. 
Table 1. Percentage of votes (number of seats won in brackets) in elections held in Bavaria

\begin{tabular}{lccc}
\hline Parties & $\begin{array}{c}2013 \\
\text { State election }\end{array}$ & $\begin{array}{c}2013 \\
\text { Federal election }\end{array}$ & $\begin{array}{c}2014 \\
\text { European election }\end{array}$ \\
\hline CSU & 47.7 & 49.3 & 40.5 \\
SPD & $(101)$ & $(56)$ & 20.1 \\
& 20.6 & 20.0 & 2.9 \\
DIE LINKE & $(42)$ & $(22)$ & 12.1 \\
& 2.1 & 3.8 & \\
GRÜNE & $(0)$ & $(4)$ & 3.1 \\
FDP & 8.6 & 8.4 & 8.1 \\
& $(18)$ & $(9)$ & 4.3 \\
AfD & 3.3 & 5.1 & \\
& $(0)$ & $(0)$ & 8.9 \\
FW & - & 4.3 & \\
& 9.0 & $(0)$ & 40.9 \\
Others & $(19)$ & 2.9 & $(0)$ \\
\hline Turnout & 8.6 & 6.2 & $(0)$ \\
\hline
\end{tabular}

Note: Percentage of votes presented in the table is based on the party votes and presents the percentage of votes parties gained in the different elections in the state of Bavaria. Given that seats for the European Parliament are allocated according to the federal results, no seat numbers can be specified for the state of Bavaria for the European election.

Table 2. Turnout percentage, broken down by gender across elections (number of respondents in brackets)

\begin{tabular}{lcccc}
\hline & Overall & State Election & Federal Election & European Election \\
\hline Men & 65 & 73 & 81 & 40 \\
& $(3,720)$ & $(1,267)$ & $(1,229)$ & $(1,223)$ \\
Women & 59 & 62 & 73 & 42 \\
& $(3,641)$ & $(1,214)$ & $(1,172)$ & $(1,254)$ \\
\hline Sign $(\mathrm{z})^{\mathbf{a}}$ & $3.01^{* *}$ & $5.96^{* * *}$ & $4.49^{* * *}$ & 0.47 \\
\hline
\end{tabular}

a Significance tests conducted through probit regression analyses with gender as the only independent variable. The standard errors are clustered by respondent when in the overall estimation $* * * \mathrm{p} \leq .001, * * \mathrm{p} \leq .01, * \mathrm{p} \leq .05$

Source: MEDW, Bavaria Panel, 2013-2014.

Table 3. Consistency in turnout broken down by gender (row percentages, number of respondents between brackets)

\begin{tabular}{|c|c|c|c|c|c|}
\hline & $\begin{array}{l}\text { Voted in all } \\
\text { elections }\end{array}$ & $\begin{array}{c}\text { Voted in two } \\
\text { elections }\end{array}$ & $\begin{array}{c}\text { Voted in one } \\
\text { election }\end{array}$ & $\begin{array}{c}\text { Voted in none of the } \\
\text { elections }\end{array}$ & Total \\
\hline Men & $\begin{array}{c}59 \\
(745)\end{array}$ & $\begin{array}{c}22 \\
(279)\end{array}$ & $\begin{array}{c}9 \\
(110)\end{array}$ & $\begin{array}{c}10 \\
(133)\end{array}$ & $\begin{array}{c}100 \\
(1,267)\end{array}$ \\
\hline Women & $\begin{array}{c}48 \\
(587)\end{array}$ & $\begin{array}{c}22 \\
(263)\end{array}$ & $\begin{array}{c}15 \\
(186)\end{array}$ & $\begin{array}{c}15 \\
(179)\end{array}$ & $\begin{array}{c}100 \\
(1,215)\end{array}$ \\
\hline $\operatorname{Sign}_{\mathbf{a}}(\mathrm{z})$ & $-5.26 * * *$ & -.23 & $5.07 * * *$ & $3.23 *$ & \\
\hline
\end{tabular}

a Significance tests conducted through binary probit regression analyses comparing every category with all the remaining categories together and with gender as the only independent variable and.

$* * * \mathrm{p} \leq .001, * * \mathrm{p} \leq .01, * \mathrm{p} \leq .05$

Source: MEDW, Bavaria Panel, 2013-2014. 
Table 4. Means/proportions and standard deviations (in brackets) for the central issue of the election, the influence of policies on well-being, and interest in the election broken down by gender and across elections

\begin{tabular}{|c|c|c|c|c|c|c|c|c|c|}
\hline & \multicolumn{3}{|c|}{ State Election } & \multicolumn{3}{|c|}{ Federal Election } & \multicolumn{3}{|c|}{ European Election } \\
\hline & Men & Women & Sign. $^{a}$ & Men & Women & Sign. $^{a}$ & Men & Women & Sign. $^{\mathrm{a}}$ \\
\hline \multicolumn{10}{|l|}{$\begin{array}{l}\text { Issue of the } \\
\text { election }\end{array}$} \\
\hline Masculine & $10.0 \%$ & $10.8 \%$ & & $17.5 \%$ & $16.7 \%$ & & $31.4 \%$ & $27.1 \%$ & $*$ \\
\hline Feminine & $4.9 \%$ & $6.8 \%$ & $*$ & $7.1 \%$ & $6.7 \%$ & & $2.7 \%$ & $2.1 \%$ & \\
\hline $\begin{array}{l}\text { Choosing } \\
\text { the best } \\
\text { people }\end{array}$ & $65.0 \%$ & $62.2 \%$ & & $61.2 \%$ & $55.8 \%$ & $* *$ & $39.2 \%$ & $40.8 \%$ & \\
\hline $\begin{array}{l}\text { Don't } \\
\text { know }\end{array}$ & $20.1 \%$ & $20.3 \%$ & & $14.2 \%$ & $21.4 \%$ & $* * *$ & $26.7 \%$ & $30.0 \%$ & \\
\hline $\begin{array}{l}\text { Influence } \\
\text { policies }\end{array}$ & $\begin{array}{c}6.13 \\
(2.39)\end{array}$ & $\begin{array}{c}6.32 \\
(2.44)\end{array}$ & & $\begin{array}{c}6.69 \\
(2.35)\end{array}$ & $\begin{array}{c}6.26 \\
(2.51)\end{array}$ & $* *$ & $\begin{array}{c}4.39 \\
(2.64)\end{array}$ & $\begin{array}{c}4.31 \\
(2.67)\end{array}$ & \\
\hline $\begin{array}{l}\text { Interest in } \\
\text { election }\end{array}$ & $\begin{array}{c}6.87 \\
(2.73) \\
\end{array}$ & $\begin{array}{c}6.07 \\
(2.73) \\
\end{array}$ & $* * *$ & $\begin{array}{c}7.74 \\
(2.67)\end{array}$ & $\begin{array}{c}6.74 \\
(3.03) \\
\end{array}$ & $* * *$ & $\begin{array}{c}4.38 \\
(2.98)\end{array}$ & $\begin{array}{c}4.40 \\
(2.82)\end{array}$ & \\
\hline
\end{tabular}

a Significance tests conducted through probit regression analyses for the issue of the election (versus all the remaining issues) and OLS regression for influence of the policies and interest in the election, with gender as the only independent variable.

$* * * \mathrm{p} \leq .001, * * \mathrm{p} \leq .01, * \mathrm{p} \leq .05$

Source: MEDW, Bavaria Panel 2013-2014. 
Table 5. Ordered probit regression analyses of turnout (maximum likelihood estimation with robust standard errors in parentheses)

\begin{tabular}{|c|c|c|c|}
\hline & Model 1 & Model 2 & Model 3 \\
\hline Female & $\begin{array}{l}-.135^{*} \\
(.069)\end{array}$ & $\begin{array}{l}-.096 \\
(.075)\end{array}$ & $\begin{array}{l}-.001 \\
(.146)\end{array}$ \\
\hline Education & $\begin{array}{c}.105 * * * \\
(.020)\end{array}$ & $\begin{array}{c}.081 * * * \\
(.021)\end{array}$ & $\begin{array}{c}.080 * * * \\
(.020)\end{array}$ \\
\hline Age & $\begin{array}{l}.012 * * * \\
(.003)\end{array}$ & $\begin{array}{l}.011 * * * \\
(.003)\end{array}$ & $\begin{array}{l}.011 * * * \\
(.003)\end{array}$ \\
\hline Urban living & $\begin{array}{c}.006 \\
(.022)\end{array}$ & $\begin{array}{l}-.037 \\
(.025)\end{array}$ & $\begin{array}{l}-.037 \\
(.025)\end{array}$ \\
\hline Married & $\begin{array}{l}.049 \\
(.083)\end{array}$ & $\begin{array}{l}.055 \\
(.088)\end{array}$ & $\begin{array}{l}.055 \\
(.088)\end{array}$ \\
\hline $\begin{array}{l}\text { Employment status } \\
\text { (Ref. Unemployed) }\end{array}$ & & & \\
\hline Full-time job & $\begin{array}{l}.050 \\
(.149)\end{array}$ & $\begin{array}{l}.106 \\
(.145)\end{array}$ & $\begin{array}{l}.109 \\
(.145)\end{array}$ \\
\hline Part-time job & $\begin{array}{l}.142 \\
(.165)\end{array}$ & $\begin{array}{l}.112 \\
(.164)\end{array}$ & $\begin{array}{l}.118 \\
(.164)\end{array}$ \\
\hline Other & $\begin{array}{l}.129 \\
(.160)\end{array}$ & $\begin{array}{l}.086 \\
(.152)\end{array}$ & $\begin{array}{l}.088 \\
(.152)\end{array}$ \\
\hline Religiosity & $\begin{array}{l}-.010 \\
(.038)\end{array}$ & $\begin{array}{l}-.005 \\
(.041)\end{array}$ & $\begin{array}{l}-.005 \\
(.041)\end{array}$ \\
\hline Union member & $\begin{array}{l}.170 \\
(.090)\end{array}$ & $\begin{array}{l}.196^{*} \\
(.097)\end{array}$ & $\begin{array}{l}.196^{*} \\
(.097)\end{array}$ \\
\hline Political knowledge & $\begin{array}{l}.254 * * * \\
(.051)\end{array}$ & $\begin{array}{l}.067 \\
(.055)\end{array}$ & $\begin{array}{l}.067 \\
(.055)\end{array}$ \\
\hline Feeling close to a political party & $\begin{array}{l}671 * * * \\
(.070)\end{array}$ & $\begin{array}{c}.415 * * * \\
(.077)\end{array}$ & $\begin{array}{c}.416^{* * *} \\
(.076)\end{array}$ \\
\hline Attachment to & & & \\
\hline Bavaria/Germany/Europe & $\begin{array}{c}.077 * * * \\
(.012)\end{array}$ & $\begin{array}{l}.029 * \\
(.014)\end{array}$ & $\begin{array}{l}.029 * \\
(.014)\end{array}$ \\
\hline $\begin{array}{l}\text { Election } \\
\text { (Ref. State) }\end{array}$ & & & \\
\hline Federal & $\begin{array}{c}.319 * * * \\
(.063)\end{array}$ & $\begin{array}{l}.197 * * \\
(.075)\end{array}$ & $\begin{array}{l}.193 * * \\
(.074)\end{array}$ \\
\hline European & $\begin{array}{c}-.574 * * * \\
(.072)\end{array}$ & $\begin{array}{c}-.393 * * * \\
(.086)\end{array}$ & $\begin{array}{c}-.395 * * * \\
(.086)\end{array}$ \\
\hline $\begin{array}{l}\text { Issue of election } \\
\text { (Ref. Masculine) }\end{array}$ & & & \\
\hline Feminine & & $\begin{array}{l}-.110 \\
(.188)\end{array}$ & $\begin{array}{l}-.008 \\
(.259)\end{array}$ \\
\hline Choosing the best people & & $\begin{array}{l}-.127 \\
(.089)\end{array}$ & $\begin{array}{l}-.056 \\
(.120)\end{array}$ \\
\hline Don't know & & $\begin{array}{l}-.208^{*} \\
(.104)\end{array}$ & $\begin{array}{l}-.189 \\
(.151)\end{array}$ \\
\hline Influence of policies & & $\begin{array}{l}-.003 \\
(.015)\end{array}$ & $\begin{array}{l}-.003 \\
(.015)\end{array}$ \\
\hline Interest in election & & $\begin{array}{c}.194 * * * \\
(.014)\end{array}$ & $\begin{array}{c}.194 * * * \\
(.014)\end{array}$ \\
\hline Female $\times$ Feminine issues & & & $\begin{array}{l}-.198 \\
(.368)\end{array}$ \\
\hline Female $\times$ Choosing the best people & & & $\begin{array}{l}-.143 \\
(.167)\end{array}$ \\
\hline Female $\times$ Don't know & & & $\begin{array}{l}-.041 \\
(.202)\end{array}$ \\
\hline Constant & $\begin{array}{c}-1.872 * * * \\
(.293)\end{array}$ & $\begin{array}{c}-1.746 * * * \\
(.329)\end{array}$ & $\begin{array}{c}-1.794 * * * \\
(.331)\end{array}$ \\
\hline Pseudo $\mathrm{R}^{2}$ & .216 & .297 & .298 \\
\hline Observations & 6,624 & 6,251 & 6,251 \\
\hline
\end{tabular}

$* * * \mathrm{p} \leq .001,{ }^{* *} \mathrm{p} \leq .01,{ }^{*} \mathrm{p} \leq .05 ;$ Source: MEDW, Bavaria Panel 2013-2014. 
Figure 1. Predicted probabilities (with 95\% confidence intervals) for turnout among women and men according to levels of interest in the election

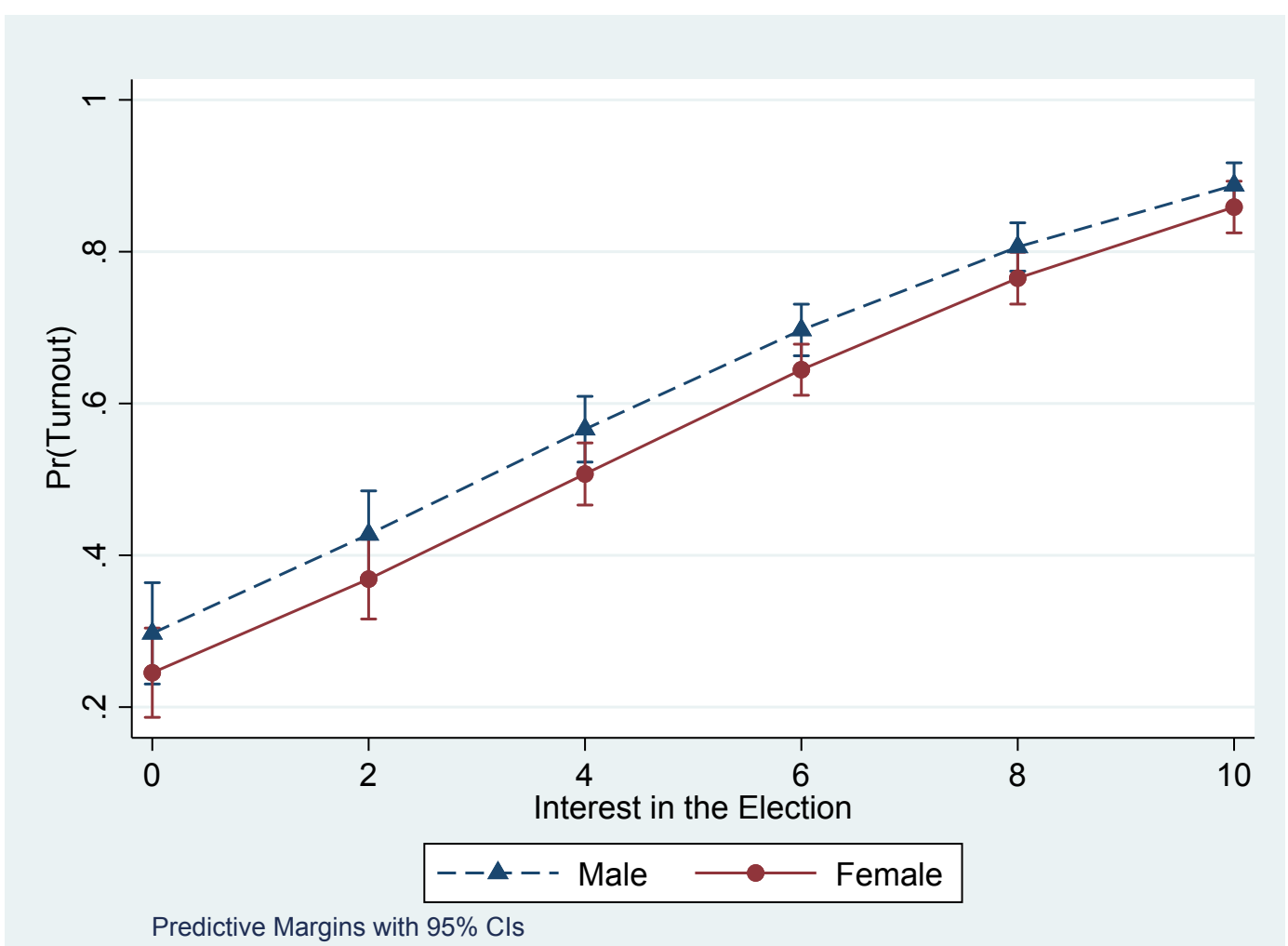

Source: MEDW, Bavaria Panel 2013-2014. 


\section{Appendix}

Table A1. Descriptive statistics for all control variables

\begin{tabular}{lcccc}
\hline & Minimum & Maximum & $\begin{array}{c}\text { Mean/ } \\
\text { Proportion }\end{array}$ & $\begin{array}{c}\text { St. } \\
\text { Deviation }\end{array}$ \\
\hline Education & 1 & 7 & 4.39 & 1.99 \\
Age & 20 & 87 & 47.86 & 13.83 \\
Urban living & 1 & 7 & 5.85 & 1.48 \\
Married & 0 & 1 & $69 \%$ & \\
Employment status & & & & \\
(Ref. unemployed) & & & & \\
$\quad$ Full-time job & 0 & 1 & $51 \%$ & \\
$\quad$ Part-time job & 0 & 1 & $16 \%$ & \\
$\quad$ Other & 0 & 1 & $24 \%$ & \\
Religiosity & 1 & 4 & 2.60 & 0.96 \\
Union member & 0 & 1 & $15 \%$ & \\
Political knowledge & 0 & 3 & 1.81 & 0.67 \\
Feeling close to a party & 0 & 1 & $49 \%$ & \\
Attachment to Bavaria & 0 & 10 & 7.88 & 2.35 \\
Attachment to Germany & 0 & 10 & 7.44 & 2.22 \\
Attachment to Europe & 0 & 10 & 5.00 & 2.76 \\
Election & & & & \\
(Ref. state) & & & & \\
$\quad$ Federal & 0 & 1 & $33 \%$ & \\
European & 0 & 1 & $34 \%$ & \\
\hline
\end{tabular}

Source: MEDW, Bavaria Panel 2013-2014. 
Table A2. Ordered probit regression analyses of turnout including influence of policies and interest in the election separately (maximum likelihood estimation with robust standard errors in parentheses)

\begin{tabular}{lcc}
\hline & Model 1 & Model 2 \\
\hline Female & -.132 & -.091 \\
& $(.072)$ & $(.071)$ \\
Influence of policies & $.033^{*}$ & \\
& $(.014)$ & \\
Interest in election & & $.200 * * *$ \\
& & $(.013)$ \\
\hline Constant & $-1.721^{* * *}$ & $-2.141^{* * *}$ \\
& $(.315)$ & $(.287)$ \\
Pseudo $\mathrm{R}^{2}$ & .215 & .304 \\
Observations & 6,376 & 6,611 \\
\hline
\end{tabular}

${ }^{* * *} \mathrm{p} \leq .001,{ }^{* *} \mathrm{p} \leq .01, * \mathrm{p} \leq .05$

Note: All models include the control variables.

Source: MEDW, Bavaria Panel 2013-2014. 
Table A3. Ordered probit regression analyses of turnout including gender interactions (maximum likelihood estimation with robust standard errors in parentheses)

\begin{tabular}{|c|c|c|c|}
\hline \multirow{3}{*}{ Female } & Model 1 & Model 2 & Model 3 \\
\hline & -.051 & .052 & $-0.278^{*}$ \\
\hline & $(.143)$ & $(.131)$ & $(.124)$ \\
\hline \multirow{2}{*}{ Education } & $.081 * * *$ & $.081 * * *$ & $.081 * * *$ \\
\hline & $(.021)$ & $(.021)$ & $(.021)$ \\
\hline \multirow[t]{2}{*}{ Age } & $.011 * * *$ & $.011 * * *$ & $.010 * * *$ \\
\hline & $(.003)$ & $(.003)$ & $(.003)$ \\
\hline \multirow[t]{2}{*}{ Urban living } & -.038 & -.037 & -.038 \\
\hline & $(.025)$ & $(.025)$ & $(.025)$ \\
\hline \multirow{2}{*}{ Married } & .055 & .056 & .056 \\
\hline & $(.088)$ & $(.089)$ & $(.089)$ \\
\hline \multicolumn{4}{|l|}{$\begin{array}{l}\text { Employment status } \\
\text { (Ref. Unemployed) }\end{array}$} \\
\hline Full-time job & .108 & .104 & .089 \\
\hline Part-time job & $\begin{array}{l}(.145) \\
.115\end{array}$ & $\begin{array}{l}(.145) \\
.118 \\
(164)\end{array}$ & $\begin{array}{l}(.145) \\
.121\end{array}$ \\
\hline \multirow{2}{*}{ Other } & $\begin{array}{c}(.164) \\
.088\end{array}$ & $\begin{array}{c}(.164) \\
.087\end{array}$ & $\begin{array}{c}(.164) \\
.087\end{array}$ \\
\hline & $\begin{array}{l}.000 \\
(.152)\end{array}$ & $(.001)$ & $\begin{array}{l}.001 \\
(.152)\end{array}$ \\
\hline Religiosity & $\begin{array}{l}-.005 \\
(.041)\end{array}$ & $\begin{array}{l}-.006 \\
(.041)\end{array}$ & $\begin{array}{l}-.006 \\
(.041)\end{array}$ \\
\hline Union member & $\begin{array}{l}.195 * \\
(097)\end{array}$ & $\begin{array}{r}.195 * \\
(097)\end{array}$ & $.199 *$ \\
\hline Political knowledge & $\begin{array}{l}.067 \\
(.055)\end{array}$ & $\begin{array}{l}.067 \\
.055)\end{array}$ & $\begin{array}{l}.060 \\
.055)\end{array}$ \\
\hline Feeling close to a political party & $415 * * *$ & $417 * * *$ & $.415 * * *$ \\
\hline Attachment to Bavaria/Germany/Europe & $\begin{array}{l}.0717 \\
.029 * \\
(.014)\end{array}$ & $\begin{array}{l}.071) \\
.029 * \\
(.014)\end{array}$ & $\begin{array}{l}.030 * \\
.030^{*} \\
(.014)\end{array}$ \\
\hline \multicolumn{4}{|l|}{$\begin{array}{l}\text { Election } \\
\text { (Ref. State) }\end{array}$} \\
\hline Federal & $\begin{array}{l}.195 * * \\
(.075)\end{array}$ & $\begin{array}{l}.196 * * \\
(.075)\end{array}$ & $\begin{array}{l}.081 \\
(.107)\end{array}$ \\
\hline European & $\begin{array}{l}-.395 * * * \\
(.086)\end{array}$ & $\begin{array}{c}-.393 * * * \\
(.086)\end{array}$ & $\begin{array}{l}-.544 * * * \\
(.114)\end{array}$ \\
\hline \multicolumn{4}{|l|}{$\begin{array}{l}\text { Issue of election } \\
\text { (Ref. Masculine) }\end{array}$} \\
\hline Feminine & $\begin{array}{l}-.109 \\
(.188)\end{array}$ & $\begin{array}{l}-.105 \\
(.187)\end{array}$ & $\begin{array}{l}-0.107 \\
(0.189)\end{array}$ \\
\hline Choosing the best people & $\begin{array}{l}-.127 \\
(.089)\end{array}$ & $\begin{array}{l}-.126 \\
(.089)\end{array}$ & $\begin{array}{l}-.129 \\
(.089)\end{array}$ \\
\hline Don't know & $\begin{array}{l}-.208^{*} \\
(.104)\end{array}$ & $-.205^{*}$ & $\begin{array}{l}-.220^{*} \\
(.105)\end{array}$ \\
\hline Influence of policies & $\begin{array}{l}.001 \\
(.020)\end{array}$ & $\begin{array}{l}-.003 \\
(.015)\end{array}$ & $\begin{array}{l}-.002 \\
(-.015)\end{array}$ \\
\hline Interest in election & $\begin{array}{l}.194 * * * \\
(.014)\end{array}$ & $\begin{array}{c}.207 * * * \\
(.019)\end{array}$ & $\begin{array}{l}.193 * * * \\
(.014)\end{array}$ \\
\hline Female $\times$ Influence of policies & $\begin{array}{l}-.008 \\
(.025)\end{array}$ & & \\
\hline Female $\times$ Interest in election & & $\begin{array}{l}-.026 \\
(.023)\end{array}$ & \\
\hline Female $\times$ Federal election & & & $\begin{array}{l}.224 \\
(.148)\end{array}$ \\
\hline Female $\times$ European election & & & $\begin{array}{l}.300^{*} \\
(.147)\end{array}$ \\
\hline Constant & $\begin{array}{l}-1.768 * * * \\
\quad(.332)\end{array}$ & $\begin{array}{c}-1.818 * * * \\
(.338)\end{array}$ & $\begin{array}{l}-1.617 * * * \\
(.339)\end{array}$ \\
\hline Pseudo $\mathrm{R}^{2}$ & .298 & .298 & .299 \\
\hline Observations & 6,251 & 6,251 & 6,251 \\
\hline
\end{tabular}

$* * * \mathrm{p} \leq .001, * * \mathrm{p} \leq .01, * \mathrm{p} \leq .05$

Source: MEDW, Bavaria Panel 2013-2014 